\title{
Saturday U. Omeluzor
}

Clifford University, Owerrinta, Nigeria

\author{
Pelemo Grace Dolapo \\ Osun State University, Osogbo,Nigeria
}

\author{
Mary Oghale Agbawe \\ Delta State Polytechnic, Ozoro, Nigeria
}

\author{
Ayoola Olusegun Onasote \\ Olabisi Onabanjo University, Ago-Iwoye, Ogun State
}

\author{
Imam Abayomi \\ Michael Otedola College of Primary Education, Lagos, Nigeria
}

\begin{abstract}
This study investigated library infrastructure as predictor of turnover intentions of academic librarians in South-South and South-East geopolitical zones of Nigeria.The study adopted a descriptive survey research design. Total enumeration method was used since the population comprising 400 academic librarians in the two geopolitical zones were considered appropriate for this study. A test-retest of the measuring instrument was done using Cronbach's alpha reliability coefficient and face validity for the reliability. The result of the reliability test 0.85 at 0.05 level of significance. From a total of 400 questionnaires that were administered and retrieved, 334 were found usable given a return rate of 83.5 percent. Findings revealed library infrastructure in academic libraries, such as air conditioners, tables, Internet facilities, library building, power supply, fire extinguishers/smoke detector and fire alarm in Nigeria with particular reference to South-South and South-East geopolitical zones were at different level of dilapidation which affected services. The result revealed that library infrastructure is a predictor of turnover intentions of librarians $(r=0.647, p<0.05)$ which indicates that an improvement in library infrastructure will reduce turnover intentions of librarians. The result showed that inadequate/unavailability of library infrastructure increase turnover intentions of academic librarians. It means that the higher the level of infrastructural deterioration in academic libraries, the higher the level of turnover intentions of academic librarians in the South-South and South-East geopolitical zones of Nigeria. This study exposed the precarious situation of academic libraries' infrastructure and its effect on librarians' turnover intentions in Nigeria.
\end{abstract}




\section{Introduction}

The university library is the centre of academic activities such as learning, teaching and research. The university library is an established and organized arm of a university with a clear mandate to provide relevant and up-to-date information resources that meet the information needs of its users. The main aim of university libraries is to acquire information resources in different formats and in various fields of human knowledge and to process, organise, disseminate and provide access to them. In order for the libraries to achieve its goal of providing information and access to its users, infrastructure and skilled personnel play a major role. In the context of this study, library infrastructures is considered in line with Ogbuagu, et al (2014) who identified infrastructure as power (generating set, electrical installations, information and communication technology facilities, furniture, fittings, information materials and library building) that contribute to the library services and the development of staff and students in a university.

Library infrastructure in most university libraries in Nigeria is moribund (Ezeani \& Igwesi, 2012) affecting the professional development of librarians and delivery of services to the library patrons. The deterioration of libraries' infrastructure can affect accreditation of courses in a university and increase the turnover intentions of librarians in university libraries. Turnover is the voluntary resignation of skilful workforce from one job to another job. The intention to quit a job is sometimes as a result of certain observable phenomenon within an organization that adversely affects the growth, career and development of employees (librarians) and their daily activities.

Employees' turnover intentions hinged on several factors and have been discussed extensively in human resources literature. Some studies such as Okoro, Omeluzor and Bamidele (2014) and Mbah and Ikemefuna (2012) reveal that job satisfaction, satisfaction with pay, job security, training and development, atrophy, unstable academic calendar are factors of turnover intentions of employees. Not a handful study has focused on university libraries' infrastructure. Therefore, this research aims at investigating library infrastructure as predictor of turnover intentions of librarians in university libraries in the two zones of Nigeria.

\section{Research objective}

This study is guided with two research objectives:

1. Identify the state of university libraries' infrastructure in Nigeria with particular reference to the South-South and South-East zones

2. Ascertain the factors that increase turnover intentions among librarians in Nigeria, with particular refence South-South and South-East zones of Nigeria.

\section{Research question}

The following research questions are meant to set the tune for this study.

1. What is the state of university libraries' infrastructure in South-South and South-East zones of Nigeria?

2. What are the factors that increase turnover intentions of librarians in South-South and South-East zones of Nigeria? 


\section{Research hypothesis}

The hypothesis was formulated to guide the study.

1. There is no significant relationship between library infrastructure and turnover intentions of librarians in university libraries in South-South and South-East zones of Nigeria.

\section{Literature review}

The invaluable disposition of libraries in the society has been discussed extensively in literature (Omeluzor, et al., 2013; Eze \& Uzoigwe, 2013). The American Library Association (2016) stated that libraries are cornerstones of the communities they serve because they provide free access to books, ideas, resources, and information for education, employment, enjoyment, and self-government. The library is central and renders multiple information services such as user education, teaching, research and provision of access to its users in all season. Mattern (2014) described the library as a bundle of "infrastructure", because the library is the single largest academic resource of last recourse (Okoro, Omeluzor and Bamidele, 2014), holding information resources and facilities that enhances access and use.

According to Iwhiwhu and Okorodudu (2012), library infrastructure include chair, bookshelves and table, toilet facilities, ICT facilities, library space, restaurant/coffee room, lighting and ventilations, parking space, catalogue system, fans and air conditioners. Jhingan (2003) cited in Ogbuagu, et al (2014) stated that infrastructure provides the basic foundation on which the take-off into self-sustaining growth is not only possible but is also assured and cumulative. Similarly, Awana (2007) asserted that library infrastructure is facilities and equipment that helps in achieving the effectiveness in the services rendered by the library. Hence, libraries of all size needs infrastructure in order to provide services to its users.

In the context of this study, library infrastructure is considered in line with Ogbuagu, et al (2014) which include power - generating set, electrical installations, furniture, fittings, information materials, library building and information communication technology (ICT) facilities. All these are identified as resources that enhance learning, teaching and research activities of a university. Okiy (2010) emphatically noted that teaching and research in tertiary institutions now demand the use of high calibre ICT infrastructure and facilities to keep abreast of current information in all fields. The Internet is an essential library infrastructure hence, Aina (2014) stated that since the advent of the Internet, libraries in developed and some developing countries have risen to the challenge by ensuring that the Internet is used to enhance the provision of information services in order to retain the patronage of the library. The Internet supports many services in university libraries such as transferring of files using file transfer protocol (FTP), emailing, newsgroups and mailing list, researching, selective dissemination of information, RSS Feed, Frequently Ask question, Ask a librarian, current awareness services and short message services (SMS).

Similarly, Haliso and Ogungbemi (2014) noted that the Internet is increasingly becoming a versatile system, providing an enormous variety of materials in different formats. One of the main reasons why most libraries provided Internet services is to give their users access to another information resource (Harrison \& Ormes, 2001). A review by Awana (2007) of modern library facilities for learning in Teachers' College revealed that Internet service in the library is another good facility that can help library users to source for information. Due to 
the importance of the Internet, academic institutions in Nigeria are now spending a substantial proportion of their budgets on ICT (Aina, 2014).

However, Okiy (2010) lamented that the dearth of ICT infrastructure and facilities in academic libraries in Nigeria is a major problem militating against globalization of information services in academic libraries in Nigeria. Folorunsho and Saka (n.d.) studied the availability of information technology (IT) in academic libraries in Kwara State, Nigeria. The study revealed that out of the seven higher institutions in Kwara State only University of Ilorin has both E-mail and Internet services, which at the time of their research was not functioning because of the difficulties in the dial up method that the library through an agent subscribed to. They noted that other libraries do not have any of the two facilities. Lack of Internet facilities in university libraries for information services could certainly lead to poor services provision to the library clientele and may increase of turnover intention of librarians.

A study by Haliso and Ogungbemi's (2014) on Internet Versuss library: coping strategies for academic librarians in Lagos State showed a disparity on the availability of library software, library website and electronic library services in six academic libraries in Lagos State. The study indicated that electronic information resources are barely available in academic libraries in Lagos State. According to Ayo (2001), most university libraries in Nigeria are yet to fully implement ICT either as a result of paucity of funds, erratic power supply, and lack of qualified personnel to drive the tool.

On the electronic power infrastructure, Akinwale (2010) and Iwayemi (2008) lamented that irregular supply of electricity is common in the Nigeria system. In the same vein, Haliso and Ogungbemi (2014) bemoaned the erratic nature of electric power supply in Nigeria which is another problem that confronts academic libraries. This situation has adversely affected the use of electronic information resources and other Internet-based resources (Omeluzor, Madukoma, Bamidele \& Ogbuiyi, 2012) that can lead to turnover intentions of librarians and job quitting from their library to better and well-equipped institutions with Internet facilities and electronic information services. Such migration caused by decay of information technology infrastructure can negatively affect the university libraries' staff strength and delivery of services.

Infrastructure is important in library services to enable the librarians deliver quality services to its clientele. It may also enhance librarians' career and productivity. However, most libraries in Nigeria have witnessed infrastructural deterioration. Iwhiwhu and Okorodudu (2012) study on public library information resources, facilities and services in Edo State Central Library, Benin-City, Nigeria revealed that some of the essential infrastructures that are necessary in delivery of services and library operations such as ICT facilities, fans and air conditioners were not available. They reported that because of unavailability of some of the essential infrastructure, users were dissatisfied.

Haliso (2011) lamented inadequate computerization, inadequate infrastructure and inadequate human capacity as the major challenges towards ICT use in academic libraries. According to Iwhiwhu and Okorodudu (2012), if the library is comfortable, it affects both the staff and users. In the same vein, Crim and Seijts (2006) stated that not giving people the knowledge and tools to be successful is unethical and de-motivating and likely to lead to stress, frustration and ultimately, lack of engagement. The library management should be able 
to provide adequate infrastructure in order for librarians to be successful in the discharge of their duties to reduce their turnover intentions.

The study by Okoro, et al. (2014) revealed that inadequate library infrastructure was a factor for the emigration of 315 librarians from academic libraries in South-West of Nigeria. Findings in the study showed that librarians from the IT sections, who were in charge of the systems, are by far the most affected accounting to $58.4 \%$ of all emigrants. Technical services took a distant second position with $23.2 \%$, whereas medical librarians were the least affected with only $1.6 \%$. Okoro, et al (2014) lamented epileptic nature of power supply, nonautomation of library processes to provide support for electronic and digital databases, unstable academic calendar, prospects for further training and lack of Internet facilities as major factors that increased the emigration of librarians. In addition, Usman (1982) reported that $75 \%$ of senior librarians resigned their jobs and emigrated to other countries from Nigeria between 1976 and 1981 as a result of unfulfilled aspirations resulting from inadequate infrastructure to provide services.

According to Bandhanpreet, Mohindru and Pankaj (2013), turnover intentions is a complex phenomenon that depends on various factors. Some researches on employees' turnover behaviour indicated that age, gender, tenure, designation, experience, compensation, education, nature of employment are predictors of turnover intentions of employees in organizations. According to Mbah and Ikemefuna (2012), turnover intentions is the rate at which an employer gain and loose employees. They emphasized that employees' turnover is not a relatively new concept in management but a typical issue in human resources management that is presently attracting the attention of public administration and industrial relations management practitioners across the world.

Some factors could be responsible for employees' turnover intentions. According to Rai (2014) factors that influence turnover of employees are lack of communication among workers and managers, work is deemed boring and non value adding, less opportunity to grow and learn, lack of recognition, over control over job and life and failure to feel the importance. Similarly, Kaur, Mohindru and Pankaj (2013) opined that employees may voluntarily leave an organization for a variety of reasons, including low satisfaction with their jobs, low satisfaction with their employer, limited promotion and growth opportunities, a better opportunity elsewhere, or disapproval of organizational changes or restructuring.

There are several factors that influences employee's retention that can be explored by academic libraries, i.e. compensation \& rewards, job security, training and developments, supervisor support culture, work environment and organization justice (Fitz-enz, 1990). Furthermore, Mbah and Ikemefuna (2012) found that satisfaction with pay, nature of work and supervision are critical to reduce employees' turnover intentions. They noted that employees feel satisfied when their pay is commensurate with the work that was done. On the nature of job, they confirmed that employees are more satisfied with their job if they are permitted to use their own abilities, judgement and methods to schedule and perform their jobs; which according to them constitute employee retention strategy of companies and thus reduces labour turnover intentions (Mbah \& Ikemefuna, 2012).

Price (1977) suggested that job satisfaction is the antecedent variable of turnover intentions; this means that satisfaction of employees has a significant negative effect on 
turnover intentions. It also implies that when employees are satisfied with the infrastructure that enables them to work, their desire to leave an organization will be reduced. Based on the above assertions, organizational commitment can be seen as an important intermediate variable (Lee, Huang, \& Zhao, 2012). Although, job satisfaction indirectly affects turnover intentions through organizational commitment, however, research showed that the level of job satisfaction can often affect turnover intention through organizational commitment (Lok \& Crawford, 2001; Parker \& Kohlmeyer, 2005).

An exploratory study on turnover intentions among private sector employees by YinFah, Foon, Chee-Leong and Osman (2010) showed that 51 respondents (42.5 per cent) experienced moderate level of turnover intention, 37 respondents (30.8 per cent) of them scored low level of turnover intention and 32 respondents (26.7 per cent) scored high level of turnover intention. The implication of this is that since some of the employees were already experiencing turnover intention, it is likely to increase if nothing is done to reduce it.

Managing turnover intentions of employees is very important. Kaur, et al (2013) suggested that since employees are the face of an organization, in order to have competitive advantage over other organizations, attention should be on the employees. Furthermore, in having a competitive edge over competing organizations, turnover has to be controlled by taking measures that are favourable to employees which may lead to increase in their commitment level (Kaur, et al (2013).Ultimately, employees are building blocks of an organization, thus their retention is a major concern. So attempts must be made to reduce turnover rate of organizations.

A study by Olusegun (2013) on the influence of job satisfaction on turnover intentions of library personnel in selected universities in South West Nigeria revealed a high mean $(\mathrm{X}=$ 2.88 , S.D $=1.07$ ) of library personnel who agreed to quit their present job for a similar position with better pay in another organization at the least opportunity. The study further shows that the respondents were not satisfied with the organization's policy on staff benefits (housing, health, transport and professional career) with mean $(X=2.60, S . D=1.04)$. According to Medina (2012), job satisfaction has a great influence on the turnover intention with 0.425-point decrease. Furthermore, Kristensen and Westergård-Nielsen (2004) found that low overall job satisfaction significantly increase the probability of quit. Another factor for turnover intentions of employees is lack of commendation. Irshad (2012) reviewed literature on the factors affecting employee retention. He stated that reward can be intrinsic or extrinsic, it can be in form of cash i.e. bonuses, etc. or reward can be in form of recognition/certificate such as 'commendation certificate' or worker of the month etc. Similarly, Sanjeevkumar (2012) in a study on employee's intention to stay in public companies, Kedah, Malaysia noted that employees in the public company value the commendation from their supervisor, especially their immediate supervisors. Consequently, employee commendation raises their self-worth and motivation and will reduce their turnover intentions.

\section{Methodology}

This study investigates library infrastructure as a predictor of turnover intentions of librarians in university libraries in Federal, State and Private Universities in South-South and 
South-East geopolitical zones of Nigeria. At the time of this study, there were twenty (20) recognized universities in South-South with 227 librarians and eighteen (18) with 173 librarians in South-East. This study did not cover the newly accredited universities in 2016. A descriptive survey research design was adopted for this study. The study used a total enumeration method since the population consisting of 400 academic librarians from the two zones were considered appropriate to achieve the purpose of this study. A questionnaire titled "Library infrastructure a predictor of turnover intentions of librarians in university libraries in South-South and South-East zones of Nigeria" was used. Before the instrument was administered on the respondents, face validity was carried out to test the validity of the questions. The questionnaire was also presented to experts who validated it, resolved defects and made some modifications. To ensure that the structured questionnaire was reliable, a pilot study was conducted using 30 librarians from Ogun State University, Ago-Iwoye, which is outside the study area. The result of the reliability test using Cronbach's alpha reliability coefficient is 0.82 . This means that the instrument was good and reliable since the test result is above the acceptance point of 0.50. The questionnaire was administered on all the respondents face to face. The researchers were assisted by two research assistants who were first taught how to administer and retrieve the instrument from the respondents. All the questionnaires were retrieved while 334 of the questionnaire were found usable given a return rate of 83.5 percent which were used for the analysis. Results were analysed using Statistical Package SS (SPSS) and are presented in percentage, mean and standard deviation. The only hypothesis in this study was tested using Pearson's Product Moment Correlation at 0.05 level of significance.

\section{Findings and discussion}

Research Question 1: What is the state of the infrastructure in university libraries in SouthSouth and South-East of Nigeria?

Table I: State of Infrastructure in university libraries in South-South and South-East of Nigeria.

\begin{tabular}{|l|l|l|l|l|l|}
\hline Library Infrastructure & $\begin{array}{l}\text { Highly } \\
\text { dilapidated }\end{array}$ & $\begin{array}{l}\text { Nearly } \\
\text { dilapidated }\end{array}$ & $\begin{array}{l}\text { Almost } \\
\text { dilapidated }\end{array}$ & $\bar{X}$ & SD \\
\hline Air conditioners & $169(50.5)$ & $65(19.5)$ & $100(30.0)$ & 3.34 & 1.21 \\
\hline Tables & $138(41.4)$ & $121(36.2)$ & $75(22.5)$ & 3.31 & 1.08 \\
\hline Chairs & $137(41)$ & $108(32.3)$ & $89(26.7)$ & 3.22 & 1.10 \\
\hline Fans & $126(37.8)$ & $100(29.9)$ & $108(32.3)$ & 3.22 & 1.12 \\
\hline Internet facilities & $122(36.6)$ & $91(27.2)$ & $121(36.3)$ & 3.02 & 1.36 \\
\hline Library building & $106(31.8)$ & $105(31.4)$ & $123(36.9)$ & 2.91 & 1.28 \\
\hline Book shelves & $101(30.3)$ & $69(20.7)$ & $164(49.1)$ & 2.90 & 1.21 \\
\hline Catalogue cabinet & $86(25.8)$ & $107(32.0)$ & $141(42.2)$ & 2.90 & 1.15 \\
\hline Lighting & $88(26.4)$ & $125(37.4)$ & $121(36.2)$ & 2.88 & 1.09 \\
\hline Power supply & $76(22.8)$ & $121(36.2)$ & $137(41.1)$ & 2.81 & 1.27 \\
\hline $\begin{array}{l}\text { Computer system and } \\
\text { accessories }\end{array}$ & $92(27.6)$ & $85(25.4)$ & $157(47)$ & 2.80 & 1.21 \\
\hline
\end{tabular}


Library infrastructure as predictor of turnover intentions of librarians in university libraries in Nigeria

\begin{tabular}{|l|l|l|l|l|l|}
\hline Smoke detector (Alarm) & $38(11.4)$ & $37(11.1)$ & $168(50.3)$ & 2.80 & 1.33 \\
\hline
\end{tabular}

Keys: $\overline{\mathrm{X}}=$ Mean, $\mathrm{SD}=$ Standard deviation

Result in table I shows that some of the library infrastructure in university libraries in the two zones were highly dilapidated; some were in a state of dilapidation, while some were almost dilapidated. From table I, air conditioner, tables, chairs, Internet facilities and power supply were highly dilapidated and nearly dilapidated. The result also shows that smoke detector (alarm) was almost dilapidated in some university libraries. This result corroborates with Okiy (2010) findings that the dearth of ICT infrastructure and facilities in academic libraries in Nigeria is a major problem militating against globalization of information services. In addition, Haliso (2011) lamented inadequate computerization and inadequate infrastructure as major challenges towards ICT use in academic libraries. The implication of this result will be an increase in turnover intentions of librarians. In the same vein, Crim and Seijts (2006) argued that not giving people the knowledge and tools to be successful is unethical and de-motivating and likely to lead to stress, frustration and ultimately disengagement.There is a correlation of the finding in Table I with that of Iwhiwhu and Okorodudu (2012) who found that some of the essential infrastructure such as ICT facilities, fans and air conditioners were not available in libraries in Edo State, Nigeria.

Research question 2: What are the factors that increase turnover intention among librarians in South-South and South-East zones of Nigeria?

Table II: Factors that increase turnover intentions of librarians in university libraries in South-South and South-East zones of Nigeria.

\begin{tabular}{|l|l|l|l|l|l|l|}
\hline Statement & $\begin{array}{l}\text { Strongly } \\
\text { agree }\end{array}$ & Agree & Disagree & $\begin{array}{l}\text { Strongly } \\
\text { disagree }\end{array}$ & $\overline{\mathrm{X}}$ & SD \\
\hline $\begin{array}{l}\text { I will leave due to } \\
\text { inadequate library } \\
\text { infrastructure. }\end{array}$ & $\begin{array}{l}(49.4) \\
\text { I am thinking of leaving } \\
\text { because of inadequate and } \\
\text { poor access to Internet } \\
\text { facilities. }\end{array}$ & $\begin{array}{l}129(8.7) \\
(38.6)\end{array}$ & $49(20.7)$ & $71(21.3)$ & 2.86 & 1.24 \\
\hline $\begin{array}{l}\text { I will resign my job due to } \\
\text { lack of computer system. }\end{array}$ & $\begin{array}{l}124 \\
(37.1)\end{array}$ & $39(11.7)$ & $104(31.1)$ & $67(20.1)$ & 2.66 & 1.17 \\
\hline $\begin{array}{l}\text { I am discouraged to work } \\
\text { due to lack of power } \\
\text { supply. }\end{array}$ & $78(23.4)$ & $137(41.0)$ & $86(25.7)$ & $33(9.9)$ & 2.77 & 0.91 \\
\hline $\begin{array}{l}\text { I will quit this job soon } \\
\text { due to poor ICT } \\
\text { infrastructure in my } \\
\text { library. }\end{array}$ & $82(24.6)$ & $181(54.2)$ & $39(11.7)$ & $32(9.6)$ & 2.93 & 0.86 \\
\hline
\end{tabular}

Key: $\bar{X}=$ Mean, SD = Standard deviation

Result in table II shows the factors that increase turnover intentions of librarians in 
university libraries in the two zones. Finding reveals that inadequate library infrastructure, inadequate and poor access to the Internet facilities, lack of power supply and poor ICT infrastructure were factors that increase turnover intentions of librarians. These factors have been found as predictors of turnover intentions and possible resignation of employees. This finding confirm the findings of Iwhiwhu and Okorodudu (2012) that unavailability of infrastructure such as ICT facilities, fans and air conditioner in libraries created dissatisfaction among librarians and library users. The finding is also supported by Okoro, et al. (2014) who found that inadequate library infrastructure was a factor for the emigration of 315 librarians from university libraries in South-West of Nigeria. The study showed that epileptic nature of power supply, non-automation of library processes to provide support for electronic and digital databases and lack of Internet facilities were major factors that increased the number of librarians that left the university libraries to other parts of the world. It can be deduced here that provision of library infrastructure reduces turnover intention;

On the other hand, result shows that lack of computer system does not significantly increase turnover intentions of librarians. This means that unavailability of computer systems in libraries has no significant effect on turnover intentions of librarians. Therefore, library management should improve their library infrastructure including Internet facilities and power supply and be committed to employees' welfare to reduce turnover intentions in university libraries.

\section{Test of Hypothesis}

The hypothesis in this study stated that there is no significant relationship between infrastructure and turnover intentions of librarians in university libraries in South-South and South-East of Nigeria. This was tested using Pearson Product Moment Correlation analysis and the result is presented in table III.

Table III: Pearson Product Moment Correlation Analysis of infrastructure with librarians' turnover intentions

\begin{tabular}{|l|l|l|l|l|l|l|}
\hline Variables & $\mathbf{N}$ & Mean & SD & $\mathbf{R}$ & Sig. & Remark \\
\hline Infrastructure & 330 & 3.02 & .841 & .647 & .000 & Significant \\
\cline { 1 - 4 } Turnover intentions of librarians & 334 & 2.76 & .757 & & & \\
\hline
\end{tabular}

*Sig at 0.05 level

Table III shows result of the relationship between library infrastructure and turnover intentions of librarians in university libraries in South-South and South-East zones of Nigeria The result indicate that infrastructure $(r=0.647, p<0.05)$ is significant and its coefficient is positive which means that, the higher the level of deterioration of library infrastructure in university libraries, the higher the level of turnover intentions of librarians. Therefore the null hypothesis is rejected. The result in table III further reveals that, there is a significant positive relationship between university library infrastructure and turnover intentions of librarians. It also means that retaining librarians in the university libraries depends on the availability and functionality of library infrastructure that enhances delivery of services, career growth and development of librarians while deteriorating library infrastructure increase librarians' turnover intentions in university libraries. 


\section{Conclusion and recommendations}

The essence and impact of library infrastructure in university libraries cannot be over emphasized. Library infrastructure is the bedrock of information acquisition, processing, organization and access. This study reveals that library infrastructure is a predictor of turnover intentions of librarians in the two zones of Nigeria and requires drastic overhauling. Therefore, the library management and university administrators should ensure adequate provision and improvement of library infrastructure in university libraries such as power supply, Internet facilities, air conditioner, computer and accessories, tables and smoke detector among others as a means of reducing turnover intentions of academic librarians.

This finding indicates that, despite the factors that have regularly shown in literature, such as lack job satisfaction, lack of commendation, better pay, reuniting with family, nature of work, supervision, limited promotion, growth opportunities and lack of communication as precursor of turnover intentions among employees, library infrastructure is a predictor of turnover intentions in university libraries in South-South and South-East of Nigeria. Therefore, inadequacy and deteriorating library infrastructure threatens the retention of librarians in university libraries.

Based on the findings, the following recommendations are made:

1. University libraries in Nigeria should improve their library infrastructure and facilities including air conditioner, library building, tables, chairs, fans and Internet facilities, book shelves, catalogue cabinet, adequate power supply to avert turnover intentions of librarians.

2. University libraries should install fire extinguishers, fire alarm and smoke detector to avoid fire disaster in university libraries.

3. University Management should support the libraries through funding to enable it acquire relevant infrastructure which will boost their moral in service delivery to library patrons as a means of reducing their turnover intentions.

\section{References}

Aina, L. O. (2014). The current practice of Librarianship: A journey to extinction of the profession in Nigeria? Being a lecture delivered at the $8^{\text {th }}$ Jire Olanlokun Memorial Lecture at the Julius Berger Hall, University of Lagos.

Akinwale, A. A. (2010). The menace of inadequate infrastructure in Nigeria. African Journal of Science, Technology, Innovation and Development, 2(3): 207-228.

Awana, B. O. (2007). Modern library facilities to enhance learning in a Teachers' College. Retrieved from www.ajol.info/index.php/afrrev/article/download/41021/8461

Ayo, T. A. (2001). Information and communication technologies and the information professionals in the information age: The Nigerian perspectives. Information Management, 6 (1), 33-43.

Bandhanpreet, K., Mohindru \& Pankaj (2013). Antecedents of turnover intentions: A literature review. Global Journal of Management and Business Studies, 3 (10): 12191230.

Crim, D. \& Seijts, G. (2006). What engages employees the most or, the ten Cs of employee 
engagement, Ivey Business Journal, March/April. pp. 1-5. Retrieved from http://iveybusinessjournal.com/publication/what-engages-employees-the-most-or-theten-cs-of-employee-engagement/

Eze, J. U. \& Uzoigwe, C. U. (2013). The place of academic libraries in Nigerian university education: Contributing to the 'Education for all' initiative. International Journal of Library and Information Science, 5 (10), 432-438.

Ezeani, C.N. \& Igwesi, U. (2012). Using social media for dynamic library service delivery: The Nigeria experience. Retrieved from http://digitalcommons.unl.edu/libphilprac/814/ (accessed on 11 April 2016).

Fitz-enz, J. (1990). Getting and keeping good employees. In personnel, 67(8): 25-29.

Folorunsho, A. L. \& Saka, H. T. (n.d.). A survey of the availability of information technology (IT) in academic libraries in Kwara State, Nigeria. International Library Movement (An Organ of ILM Foundation) India. Retrieved from https://www.unilorin.edu.ng/publications/alfolorunsho/A\%20Survey\%20of\%20the $\% 20$ Availability\%20of\%20I\%20T\%20in\%20Academic\%20Libraries.pdf

Haliso, Y. \& Ogungbemi, J. I. (2014). Internet Vs Library: Coping strategies for academic librarians in Lagos State, Nigeria. Information and Knowledge Management, 4 (1): 5864.

Haliso, Y. (2011). Factors affecting information and communication technologies (ICTs) use by academic librarians in Southwester Nigeria. Retrieved from http://www.webpages.uidaho.edu/ mbolin/haliso.htm

Harrison, J. \& Ormes, S. (2001). Internet services: the range available to library users. Retrieved from http://www.ukoln.ac.uk/public/earl/issuepapers/range.html

Irshad, M. (2012). Factors affecting employee retention: Evidence from literature review. Abasyn Journal of Social Sciences, 4 (1): 84-102.

Iwhiwhu ,B. E. \& Okorodudu, P.O. (2012). Public library information resources, facilities, and services: User satisfaction with the Edo State Central Library, Benin-City, Nigeria. Library Philosophy and Practice. Retrieved from http://unllib.unl.edu/lpp.retrieved

Kaur, B., Mohindru, \& Pankaj (2013). Antecedents of turnover intentions: A literature review. Global Journal of Management and Business Studies, 3(10): 1219-1230.

Kristensen, N. and Westergård-Nielsen, N. (2004). Does low job satisfaction lead to job mobility? IZA Discussion paper No. 1026.

Lee, M. (2009). Growing librarians: Mentorship in an academic library. Library Leadership \& Management, 23(1): 31-37.

Lok, P. \& Crawford, J. (2001). Antecedents of Organizational Commitment and the Mediating Role of Job Satisfaction. Journal of Managerial Psychology, 16 (8): 94-612.

Mattern, S. (2014). Library as infrastructure: Reading room, social service center, innovation lab. How far can we stretch the public library? Retrieved from https://placesjournal.org/article/library-as-infrastructure/

Mbah, S. E. \& Ikemefuna, C. O. (2012). Job satisfaction and employees' turnover intentions in Total Nigeria Plc. in Lagos State. International Journal of Humanities and Social Science. 2(4): 275-287.

Medina, E. (2012). Job satisfaction and employee turnover intention: What does 
organizational culture have to do with it? p.23. Retrieve from http://static1.1.sqspcdn.com/static/f/1528810/23319899/1376576545493/Medina+Eliza beth.pdf

Ogbuagu, U., Ubi, P. \& Effiom, L. (2014). Corruption and infrastructural decay: perceptible evidence from Nigeria. Journal of Economics and Sustainable Development, 5 (10): 2027.

Okiy, R. B. (2010). Globalization and ICT in academic libraries in Nigeria: The way forward. Library Philosophy and Practice. Retrieved from http://www.webpages.uidaho.edu/ mbolin/okiy.htm

Okoro, C.C., Omeluzor, S. U. \& Bamidele, I. A. (2014). Effect of brain drain (human capital flight) of librarians on service delivery in some selected Nigerian universities. Sage Open, 1-11.

Olusegun, S. O. (2013). Influence of job satisfaction on turnover intentions of library personnel in selected university in South West Nigeria. Library Philosophy and Practice (e-journal), Retrieved from http://digitalcommons.unl.edu/cgi/viewcontent.cgi?article=2267\&context=libphilprac

Omeluzor, S. U., Bamidele, I.A, Ukangwa, C.C \& Amadi H.U. (2013). The relevance of a library in the $21^{\text {st }}$ Century: Students' perception. International Journal of Library and Information Science, 5 (6): 160-167.

Omeluzor, S.U., Madukoma, E., Bamidele, I. \& Ogbuiyi, S. U. (2012). Use of electronic information resources and research output by academic staff in private universities in Ogun State, Nigeria. Canadian Social Science, 8 (3): 8-15.

Parker, R.J. \& Kohlmeyer, J.M. (2005). Organizational justice and turnover in public accounting firms: A research note. Accounting, Organizations and Society, 30, 357369.

Price, J.L. (1977). The study of turnover, Ames: the Iowa State University Press.

Rai, S. (2014). Retaining talent and understanding work values: Indian experience. Review of Contemporary Business Research. 3 (2): 87-95.

Sanjeevkumar, V. (2012). A study on employee's intention to stay in public companies, Kedah, Malaysia. Zenith International Journal of Business Economics \& Management Research. 2 (4), 91-101.

Usman, M. A. (1982). The brain drain phenomenon: Case of university libraries in Northern Nigeria. Library Focus, 8 (1): 12-22.

Yin-Fah, B. C., Foon, Y.S., Chee-Leong, L. \& Osman, S. (2010). An exploratory study on turnover intention among private sector employees. International Journal of Business and Management, 5 (8): 57-64.

Saturday U. Omeluzor, Ph.D is the University Librarian Clifford University Owerrinta, Ihie Campus, Aba, Nigeria. He can be reached atsomeluzor@yahoo.com, dromeluzor@gmail.com

Pelemo Grace Dolapo is a librarian with Osun State University, Osogbo,Nigeria

Mary Oghale Agbawe is librarian Delta State Polytechnic, Ozoro, Nigeria

Ayoola Olusegun Onasote is of the Olabisi Onabanjo University Library, Ago-Iwoye, Ogun State.

Imam Abayomi

Michael Otedola College of Primary Education, Noforija Epe, Lagos State 